\title{
Peran Komite Independen Sadar Pemilu (KISP) sebagai LSM Kepemiluan dalam Melawan Praktik Politik Uang
}

\section{The Role of Komite Independen Sadar Pemilu (KISP) as the Election Ngo to Against Money Politic Practice}

\author{
Fairuz Arta Abhipraya ${ }^{1}$, Delila Putri Sadayi ${ }^{2}$, Febriana Andiani Putri ${ }^{3}$ \\ 1,2,3 Ilmu Pemerintahan, Universitas Muhammadiyah Yogyakarta \\ Jl.Brawijaya, Gebglagan, Tamantirto, Kec.Kasihan,Bantul, Daerah Istimewa Yogyakarta \\ *corresponding author E-mail: fairuz.arta23@gmail.com
}

Diterima: 18 Mei 2020; Direvisi: 7 Juni 2020; Disetujui:15 Juni 2020

\begin{abstract}
ABSTRAK
Artikel ini mencoba menguji keberhasilan peran LSM kepemiluan Komite Independen Sadar Pemilu (KISP) dalam membentuk desa anti politik uang (desa APU) sebagai agenda perlawanan terhadap praktik politik uang di Desa Sardonoharjo, Kecamatan Ngaglik, Kabupaten Sleman, Daerah Istimewa Yogyakarta. Artikel ini menggunakan metode penelitian kualitatif dengan pendekatan deskriptif yang menggunakan instrumen wawancara terhadap informan terkait dan menggunakan instrumen observasi participan pada objek penelitian sebagai data primer, sedangkan data sekunder diperoleh dari studi perpustakaan terkait fokus penelitian seperti buku, jurnal nasional/internasional, laporan, dokumen dan sumber tertulis lainya yang terkait dengan fokus penelitian. Artikel ini mengarahkan kepada 4 kesimpulan pokok: 1.) Peran KISP sebagai konseptor pembentukan Desa APU meliputi deklarasi Desa APU untuk melawan praktik politik uang, pembentukan tim, sosialisasi dan pendidikan tentang bahaya politik uang, hingga pada pembuatan modul Desa APU dan pembuatan stiker keluarga anti politik uang. 2.) Masih ada penolakan oleh masyarakat sekitar terkait gerakan perlawanan politik uang. 3.) Peran KISP dalam pembentukan Desa APU untuk melawan praktik politik kurang efektif mengurangi terjadinya praktik politik uang, meskipun tidak ditemukan laporan mengenai praktik politik uang di Desa Sardonoharjo hal ini tidak mengindikasikan keberhasilan program Desa APU. 4.) Hal ini disebabkan karena politik uang sudah menjadi hal yang biasa dikalangan masyarakat sekitar desa tersebut dan sikap kurang tegas dari pihak perangkat desa, serta kurangnya partisipasi dari pihak Bawaslu Kabupaten Sleman pada tahapan sosialisasi.
\end{abstract}

Kata Kunci: KISP, LSM Kepemiluan, Pemilu, Politik Uang

\section{ABSTRACT}

This article tries to examine the success of the role of Komite Independen Sadar Pemilu (KISP) as the NGO in forming Anti-money politic village (Desa APU) as an agenda to against money politic practice in Sardonoharjo village, Ngaglik 
district, Sleman Regency, Special region of Yogyakarta. This article uses qualitative research methods with a descriptive approach. The source of this article is obtained from interviewi instruments to the related informant and uses participant observation instruments on research objects as primary data, while secondary data is obtained from library studies such as books, national/international journal, documents, reports and the written source related to research focus. This article leads to 4 Principal conclusions: 1.) The role of KISP as the conceptor to forming Desa APU includes the declaration of Desa APU to against money politic, forming a team work, socialization and education about the dangerous of money politics, forming a module/book for Desa APU and create a sticker for anti-money politic family 2.) There was still rejection by the surrounding communities related to the movement against money politics practice 3.) The role of KISP in forming Desa APU to against money politics was less effective to reduce money politics practice, although there was no report for the occurrence of money politics practice in Sardonoharjo village it does not indicate the success of Desa APU program.4.) This is because money politics has become a normal thing among the community and the attitude of less forceful of the village stakeholders, as well as the lack of participation from BAWASLU Sleman Regency at the stage of socialization.

Keywords: KISP, Electoral NGOs, Election.

\section{PENDAHULUAN}

Penyelenggaraan Pemilihan Umum (Pemilu) di Indonesia memiliki fungsi sebagai sarana bagi para politisi yang akan mewakili dan membawa suara masyarakat di dalam lembaga perwakilan. Mereka yang terpilih dianggap sebagai orang atau kelompok yang mempunyai kemampuan atau kewajiban untuk bicara dan bertindak atas nama suatu kelompok yang lebih besar melalui partai politik. Oleh sebab itu, adanya partai politik merupakan keharusan dalam kehidupan politik, khususnya pada sistem demokrasi prosedural. Hal itu dimaksudkan untuk mengaktifkan dan memobilisasi rakyat, mewakili kepentingan tertentu, memberi jalan kompromi bagi pendapat yang berlawanan, serta menyediakan sarana suksesi kepemimpinan politik secara sah dan damai (Manan \& SH, 2018).

Pemilu juga menjadi salah satu elemen penting dalam legitimasi bagi negara yang menganut sistem demokrasi. Di Indonesia sendiri, Pemilu dilaksanakan setiap 5 tahun sekali dalam setiap periodenya untuk memilih kandidat yang akan menduduki posisi legislatif dan eksekutif. Indonesia punya 
pengalaman menggelar 11 kali pemilu. Terbaru, Indonesia melaksanakan Pilkada serentak tahun 2018 dan pemilihan legislatif (pileg) dan pemilihan presiden (Pilpres) secara serentak pada 17 April 2019. Namun dalam sejarah pemilu Indonesia, setiap tahapan dalam melanggengkan legitimasi demokrasi melalui pemilu menimbulkan banyak sekali tantangan salah satunya adalah politik uang yang disebut-sebut sebagai salah satu penyakit demokrasi. didalam Putra, Sunarto, and Raharjo (2018) politik uang adalah sebuah tindakan jual beli suara dalam bentuk materi atau imbalan yang diberikan oleh pribadi atau partai politik pada demokrasi elektoral, dengan tujuan mempengaruhi suara konstituen pada pemilu. Politik uang merupakan hal yang krusial dan perlu dicegah mulai dari masyarakat sipil, penyelenggara pemilu hingga para peserta pemilu, yaitu partai politik.

Sejarah kelam yang membuat kualitas demokrasi di indonesia semakin memburuk salah satunya adalah peristiwa politik uang di tahun 2014. Pada tahun 2014 dinilai sebagai tahun dimana politik uang paling 'vulgar' sepanjang kepemiluan di indonesia. Berdasarkan pernyataan Deputi Koordinator Jaringan Pendidikan Pemilih untuk Rakyat (JPPR) Masyukurudin Hafidz, pemberian politik uang di pemilu biasanya dilakukan secara tersembunyi dan terselubung di balik acara-acara yang dilaksanakan oleh para caleg, tetapi pada Pemilu 2014 politik uang dilakukan secara terbuka dengan membagikan amplop berisikan uang tunai secara terang-terangang. JPPR sendiri telah melakukan pemantauan di 25 provinsi di Indonesia untuk meneliti indikasi terjadinya politik uang. Sebanyak 1005 tempat pemungutan suara (TPS) dipantau oleh JPPR dan diketahui bahwa sebanyak 33\% dari TPS di 25 provinsi terindikasi melakukan praktik politik uang dengan berbagai modus dari membagikan uang tunai sebesar Rp.20.000 hingga Rp.200.000, barangbarang sembako sampai dengan polis asuransi. Jika dibandingkan pada pemilu periode sebelumnya yang hanya berkisar 10\% maka pemilu 2014 naik drastis hingga 33\% besarnya (Muhtadi, 2013).

Sedangkan untuk pemilu serentak 2019, Pusat Penelitian Politik (P2P) 
di Lembaga Ilmu Pengetahuan Indonesia (LIPI) telah melakukan penelitian terhadap pemilu serentak 2019 dan demokrasi di Indonesia. Salah satu fenomena yang menjadi penelitianya adalah mengenai politik uang di pemilu serentak 2019. Dilansir di laman berita Balicitizen.com , Wawan Ichwanudin selaku peneliti P2P LIPI menjelaskan bahwa sebesar 38\% responden mengaku menerima pemberian politik uang dari caleg atau partai politik, hal yang menjadi parahnya lagi Wawan menjelaskan bahwa $47 \%$ responden menganggap bahwa politik uang merupakan hal yang biasa dan sudah 'lumrah' untuk dilakukan (Chandra \& Ghafur, 2020).

Berdasarkan kasus-kasus politik uang yang terjadi di pengalaman penyelenggaraan pemilu sebelumnya, hal ini bisa mengindikasikan sebuah trend bahwasanya politik uang merupakan sebuah 'budaya' negatif yang selalu terjadi di setiap periode pemilu. Pola relasi hubungan politik uang mampu menciptakan pola Klientalisme. Menurut Magaloni dalam Sumarto (2018), klientelisme diartikan sebagai suatu relasi personal dua arah, yaitu asimetris dan resiprokal yang terjadi antara patron dan klien dengan memberi materi sebagai timbal balik dari klien dalam bentuk dukungan. Sedangkan menurut Aspinall and Sukmajati (2016) lebih meneka nkan bahwasanya pola klientalisme akan terjadi jika adanya pertemuan antara kedua belah pihak untuk terjadinya sebuah pertukaran antara suara dan barang patron.

Budaya politik uang yang sudah mengakar di penyelenggaraan pemilu di Indonesia sebenarnya adalah bentuk 'penindasan' melalui hubungan patron-klien antara caleg dan calon pemilih. Hal ini dijelaskan oleh Edward Aspinall dan Ward Berenschot (2019) dalam bukunya yang berjudul Democracy For Sale, bahwasanya relasi patron-klien yang tercipta dari distribusi politik uang ke masyarakat sama dengan relasi antara tuan tanah dan para penggarap lahan seperti dahulu. Dahulu para kaum borjuis (tuan pemilik tanah) mempekerjakan kaum proletar untuk menggarap lahan yang dimiliki oleh tuan pemilik tanah atau si kaum borjuis, timbal balik yang diberikan oleh tuan pemilik tanah adalah memberikan bantuan berupa 
keamanan, kepastian ekonomi dan membantu kaum proletar (masyarakat) saat dalam keadaan terdesak.

Hal ini merupakan hubungan patron-klien antara tuan tanah dan kelompok proletar, hal yang sama terjadi di hubungan patron-klien antara caleg dan calon pemilih, jika caleg berhasil memenangkan pemilu dengan menggunakan media politik uang sebagai 'penyandera' suara mereka (calon pemilih), maka caleg akan memberikan hal serupa berupa kemudahan akses publik dan barang yang nantinya akan didistribusikan setelah mereka terpilih nantinya. Bahkan jika sistem politik uangnya diberikan pasca pemilihan, maka politik uang akan diberikan setelah masyarakat memilih caleg yang bersangkutan dan barang patron tersebut (politik uang) menjadi balasan kepada pemilih karena telah memberikan suara mereka kepada caleg yang bersangkutan.

Relasi politik uang yang tercipta antara caleg dan masyarakat merupakan sebuah bentuk 'penindasan' di zaman modern yang memperkeruh kualitas demokrasi, karena masyarakat sipil diposisikan sebagai objek yang bisa dieksploitasi suaranya dalam pemilu menggunakan barang patron. Menurut Antonio Gramsci di dalam Culla (1999), masyarakat sipil dapat menggolongkan dirinya secara independen dari negara dan berhak memiliki landasan pengetahuan yang bisa membedakan dirinya dari masyarakat lainya yang tidak kritis serta pasif dalam struktur sosial yang bisa jadi menindas mereka, dalam pendekatan ini masyarakat sipil memposisikan diri mereka sebagai kelompok yang terus melakukan upaya perubahan dalam bidangbidang sosial, ekonomi dan politik serta kontrol terhadap negara untuk menghindari penindasan yang dilakukan kelompok yang lebih kuat dalam bentuk apa pun.

Dalam membahas politik uang dan masyarakat sipil, hasil penelitian dari Pranata (2019) dalam studinya yang berfokus dalam penguatan masyarakat sipil untuk melawan politik uang melalui Desa Anti Politik Uang di Desa Murtigading Yogyakarta menyebutkan bahwasanya masyarakat sipil 
memiliki inisiasinya tersendiri untuk bergerak melawan politik uang melalui program Desa Anti Politik Uang, namun antusiasme masyarakat sipil di desa tersebut tidak direspon positif oleh pemerintah khususnya penyelenggara pemilu ditingkat kabupaten dan provinsi. Hal ini sejalan dengan studi dari Marsudi \& Sunarso (2019) yang menyebutkan bahwasanya gerakan grassroot yang tumbuh di kalangan masyarakat sangat penting dalam melawan praktik politik uang, penyebutan kampung anti politik uang merupakan sebuah bentuk kesadaran kolektif masyarakat yang mampu menimbulkan efek domino untuk menginspirasi daerah lain dalam strategi melawan praktik politik uang, strategi ini mengandalkan kekuatan masyarakat sipil dalam menekan angka terjadinya praktik politik uang dari gerakan grassroot.

Namun dalam studi yang dikemukakan oleh Lukmajati (2016) menemukan bahwasanya agenda melawan praktik politik uang tidak selamanya berjalan baik, karena mayoritas laporan masyarakat sipil mengenai politik uang kepada Badan Pengawas Pemilu (Bawaslu) hanya menjadi sebatas tuduhan saja tanpa ada tindak lanjut yang jelas. Hal ini dikarenakan kurangnya bukti yang memadai dan jarang masyarakat yang ingin menjadi saksi dalam proses penyelidikan kasus politik uang. Selain itu, menjadi kelemahan masyarakat dalam melawan politik uang mengingat peran Bawaslu juga penting dalam agenda perlawanan politik uang. Sedangkan dalam studi Kurniawan (2019) mencoba memaparkan metode perlawanan politik uang dengan menggunakan konsep modal sosial, upayanya pencegahan praktik politik uang dilihat dari sisi sosiologis dan psikologis pemilih untuk ditanamkan sisi kognitifnya mengenai keburukan politik uang.

Studi yang dikemukakan oleh Anggraeni (2018) mencoba menawarkan konsep dengan kebijakan non penal untuk melawan praktik politik uang, cara yang ditawarkan adalah menggunakan lembaga pendidikan baik formal, informal maupun non formal sebagai sarana edukasi politik untuk menolak praktik politik uang serta dibutuhkan kesadaran masyarakat yang tinggi dalam mendukung tawaran tersebut. Sejalan dengan studi dari Anggraeni, 
studi dari Setyawan (2013) lebih menekankan bagaimana strategi menekan angka praktik politik uang dengan meningkatkan kesadaran kolektif pemilih pemula yang masih duduk di bangku Sekolah Menengah Atas (SMA)/sederajat melalui penyelenggara pemilu Komisi Pemilihan Umum (KPU) untuk melakukan sosialisasi di institusi pendidikan, membuat konten kreatif di sosial media mengenai bahaya politik uang, membuat politics corner di tempat publik sebagai pusat layanan informasi pemilu dan membuat buku panduan oleh KPU.

Sedangkan studi dari Mukhsid (2015) lebih mengemukakan bagaimana peran panitia pengawas pemilu untuk melakukan pengawasan terhadap beredarnya praktik politik uang, hal ini dinilai kurang efektif untuk melawan praktik politik uang karena dalam tataran penyelenggara pemilu seperti di panitia pengawas pemilu hanya berfokus pada mekanisme pengawasan, bukan pada pencegahan.

Dari penelitian terdahulu mengenai gerakan perlawanan praktik politik uang telah menawarkan berbagai alternatif melawan praktik politik uang dan tantangan masyarakat dalam melawan praktik politik uang. Namun belum ada penelitian yang mencoba berfokus pada gerakan Lembaga Swadaya Masyarakat (LSM) yang memang berfokus dalam isu kepemiluan dan demokrasi untuk melawan praktik politik uang, mayoritas penelitian hanya berfokus pada penawaran konsep perlawanan politik uang dan terlalu berfokus kepada kekuatan masyarakat sipil yang tidak terorganisir secara baik di dalam LSM untuk gerakan perlawanan praktik politik uang. Belum ada penelitian yang mencoba berfokus terhadap peran LSM yang berfokus untuk melawan praktik politik uang, padahal gerakan LSM sangatlah penting dalam proses penguatan masyarakat sipil untuk melawan hal buruk di bidang sosial, politik, ekonomi dan lain sebagainya.

LSM merupakan organisasi non-pemerintah yang dibentuk oleh individu atau kelompok secara sukarela yang memiliki tujuan untuk menopang kepentingan publik tanpa memiliki maksud untuk mengambil 
keuntungan finansial, dengan demikian LSM merupakan sebuah organisasi yang terbentuk dari masyarakat kritis akan keadaan sosial dengan ruang yang terletak antara negara di satu pihak dan masyarakat di pihak lainya. Afan Gaffar, sebagaimana mengutip pendapat dari Michael Walker, berpendapat bahwa dalam ruang tersebut terdapat asosiasi masyarakat sipil yang bersifat sukarela dan terbangun jaringan antara asosiasi tersebut.

Studi mengenai bagaimana kekuatan masyarakat sipil memperkuat kualitas demokrasi memang sudah berkembang begitu pesat, bahkan oleh Sammuel Huntington (1993) menyebutkan fenomena ini sebagai "gelombang demokratisasi ketiga" (Third Wave of Democratization), gelombang demokratisasi ketiga yang dimaksud oleh Huntington adalah mengenai bagaimana kekuatan masyarakat sipil mampu mengurangi legitimasi kekuasaan pemerintah yang dianggapnya 'menindas' demi tercapainya demokrasi yang lebih stabil, Intinya adalah kekuatan masyarakat sipil yang lebih dominan. Pada konteks pembahasan ini, LSM sebagai bagian dari masyarakat sipil memiliki peranan penting dalam memberikan kontribusi untuk menguatkan masyarakat sipil.

Tesis utama dalam konteks pembahasan penelitian ini adalah mengenai bagaimana kekuatan LSM kepemiluan mampu menjadi bagian penting bersama masyarakat sipil untuk memperkuat proses demokratisasi. Dalam konteks penelitian ini, LSM yang berangkat dari kesadaran masyarakat kritis dan memiliki agenda memperkuat masyarakat sipil dalam proses demokratisasi merupakan agen kunci proses tersebut. Sedikitnya ada tiga alasan yang mendasari LSM untuk menjadi kunci penting untuk memperkuat masyarakat sipil. Pertama, LSM memiliki keunggulan komparatif jika dibandingkan dengan lembaga pemerintah dan bisnis, LSM lebih fleksibel, memiliki jaringan yang luas, terbiasa bekerja secara organisasi bersama komunitas akar rumput dan lain sebagainya. Kedua, jika merujuk pada Zubaedi (2016), LSM memiliki fungsi mediating structures sebagai penghubung kepentingan masyarakat sipil dan negara. Dan, ketiga anggapan mengenai sel 
dari LSM merupakan sebuah anggapan bahwa LSM adalah inti dari proses penguatan masyarakat sipil dan demokratisasi.

Membahas mengenai peran LSM, maka tidak jauh dengan konsep kerelawanan (volunteerism). Hal tersebut sejalan dengan Wilson (2012) yang mengemukakan bahwa fenomena volunteerism adalah aktivitas pemberian waktu secara percuma untuk memberikan bantuan kepada orang lain, kelompok dan organisasi. Di sisi lain studi dari David G. Myers (2012) mengutarakan pendapat tentang pengertian relawan adalah orang yang memiliki hasrat untuk membantu sesama tanpa mengharapkan imbalan. Konsep ini lebih dikenal dengan penyebutan altruisme atau biasa kita sebut sebagai "ikhlas" dan "rela".

LSM yang memiliki fokus dalam perlawanan praktik politik uang serta bergerak di bidang kepemiluan dan demokrasi, meskipun semua elemen masyarakat memiliki hak untuk melawan politik uang, tetapi LSM yang bergerak di bidang kepemiluan dan demokrasi yang juga bagian dari masyarakat sipil lebih memiliki gerakan yang terstruktur dan menaruh perhatian lebih kepada isu ini. Ada beberapa LSM pemilu di Indonesia antara lain Jaringan Pendidikan Pemilih untuk Rakyat (JPPR), Forum Rektor, Komite Independen Pemantau Pemilu (KIPP), Perkumpulan untuk Pemilu dan Demokrasi (Perludem), Net Grit, Sindikasi Pemilu dan lain sebagainya. Namun, semua LSM pemilu berpusat di Jakarta. Lalu, bagaimana yang berada di daerah? Hal ini mengindikasikan ada sebuah ketimpangan demokrasi di Indonesia mengenai kekuatan masyarakat sipil yang membangun LSM kepemiluan.

Di Daerah Istimewa Yogyakarta ada sebuah LSM kepemiluan dan demokrasi yang dikenal dengan nama Komite Independen Sadar Pemilu (KISP). KISP merupakan perkumpulan yang bergerak dalam menyampaikan pesan moral atau nilai-nilai kepemiluan kepada masyarakat umum. LSM yang berdiri pada 5 April 2018 mendasari basis berdirinya dari alasan mengenai tidak percayanya KISP terhadap penyelenggara pemilu, KPU dan Bawaslu, 
untuk mampu mengerjakan tugasnya secara maksimal, sehingga mereka membutuhkan sebuah gerakan kerelawanan (volunteerism) dan KISP hadir sebagai gerakan kerelawanan tersebut.

Hal yang menjadi menarik dari KISP adalah keberadaanya yang berada di luar kota besar seperti Jakarta dan tumbuh secara independen sebagai LSM kepemiluan di Yogyakarta, karena semua LSM kepemiluan tumbuh dan berkembang sebagai penopang kekuatan demokrasi berpusat di Jakarta. Hal yang menjadi menarik lainya adalah KISP tumbuh di Yogyakarta sebagai kota yang mendapat gelar sebagai Daerah Istimewa dan tidak memiliki sistem pemilihan gubernur karena jabatan tingkat gubernur dirangkap oleh sistem kesultanan.

Berdasarkan latar belakang yang telah peneliti paparkan, maka penelitian ini akan berfokus pada bagaimana peran LSM kepemiluan, khususnya KISP, untuk melakukan perlawanan terhadap praktik politik uang. Studi mengenai bagaimana peran LSM kepemiluan dalam memperkuat masyarakat sipil untuk memperkuat kualitas demokrasi memang sudah berkembang pesat, namun semua studi tersebut berfokus pada LSM yang tumbuh dan berkembang di Jakarta, namun belum ada studi yang membahas bagaimana peran LSM kepemiluan yang tumbuh dan berkemang di daerah (non-ibu kota). Maka dari itu peneliti mengangkat judul "Peran Komite Independen Sadar Pemilu (KISP) Sebagai LSM Kepemiluan Dalam Melawan Praktik Politik Uang".

\section{METODE PENELITIAN}

Artikel ini merupakan penelitian dengan pendekatan kualitatif dan jenis deskriptif. Penelitian kualitatif adalah penelitian yang dilakukan dalam pengaturan tertentu yang ada dalam kehidupan nyata dengan maksud menyelidiki dan memahami fenomena, tujuannya adalah untuk menyelidiki apa yang terjadi, mengapa itu terjadi dan bagaimana itu terjadi (Hermawan, 2019). Pendekatan deskriptif dapat diartikan sebagai prosedur pemecahan masalah yang diselidiki dengan menampilkan gambaran keadaan subyek atau obyek penelitian seperti individu, lembaga, kelompok dan masyarakat pada 
POLITICON : Jurnal Ilmu Politik Vol.2 No.2 ; Hal 165-190

Website : http://journal.uinsgd.ac.id/index.php/politicon

\section{ISSN : 2685-6670 ( Online )}

saat sekarang berdasarkan fakta yang tampak dan lain sebagainya (Nawawi, 2015).

Data Primer yang digunakan berasal dari wawancara tiga informan kunci, yaitu Koordinator Umum Komite Independen Sadar Pemilu (KISP), satu komisioner Bawaslu Kabupaten Sleman, dan Kepala Desa Sardonoharjo. Dalam pengumpulan data, penelitian ini menggunakan teknik observasi participant, peneliti turut terlibat bersama objek penelitiannya guna mengamati fenomena-fenomena yang terjadi di lapangan dan menganalisisnya.

Data sekunder diperoleh dari buku-buku, jurnal internasional/nasional, dan dokumen lainnya terkait politik uang, Peran masyarakat sipil dalam pengawasan pemilu, dan peran lembaga swadaya masyarakat dalam pengawasan pemilu. Penghimpunan data penelitian juga dilakukan melalui proses penelaahan dan analisis mendalam terhadap hasil wawancara, jurnal dan dokumen-dokumen ataupun laporan yang berkaitan dengan fokus penelitian. Peneliti mengkaji hipotesis awal pada subjek yang terkait dengan data yang telah dikumpulkan, kemudian peneliti berupaya menganalisis data yang diperoleh dari penelitian dengan induktif. Teknik analisis induktif didefinisikan sebagai membentuk kesimpulan yang bersifat umum atau spesifik berdasarkan pengumpulan data (Sumarmo, 2010).

\section{TEMUAN DAN PEMBAHASAN}

\section{Peran KISP dalam Pembentukan Desa APU}

Desa Sardonoharjo yang berlokasi di Kecamatan Ngaglik, Kabupaten Sleman Daerah Istimewa Yogyakarta merupakan desa yang memiliki sebuah program yang bernama Desa Anti Politik Uang (Desa APU) dengan tujuan mengentaskan praktik politik uang menjelang Pemilu Serentak 2019. Menurut Sekretaris Desa Sardonoharjo, program ini pertama kali diinisiasikan oleh salah satu tokoh masyarakat wanita sebagai warga setempat yang didasari oleh keresahan untuk menghadirkan sebuah perubahan positif di desa Sardonoharjo dan perangkat desa menyambut baik hal tersebut serta mereka 
POLITICON : Jurnal Ilmu Politik Vol.2 No.2 ; Hal 165-190

Website : http://journal.uinsgd.ac.id/index.php/politicon

ISSN : 2685-6670 ( Online )

memiliki hak untuk mengapresiasi undang-undang pemilu mengenai larangan politik uang.

Artinya bahwa gerakan grassroot untuk melawan praktik politik uang dari kesadaran salah satu masyarakat Desa Sardonoharjo sudah menjadi langkah awal penting pembentukan Desa APU. Namun dengan alasan keterbatasan sumber daya manusia, gerakan Desa APU mulai mengepakan sayap dengan meminta KISP untuk membantu dalam konsep pembentukan desa APU. KISP membantu sebagai pendorong roadmap program Desa APU sebagai salah satu pilot project dari Bawaslu Kabupaten Sleman yang sebelumnya program Desa APU di Desa Sardonoharjo bukan salah satu pilot project dari Bawaslu Kabupaten Sleman.

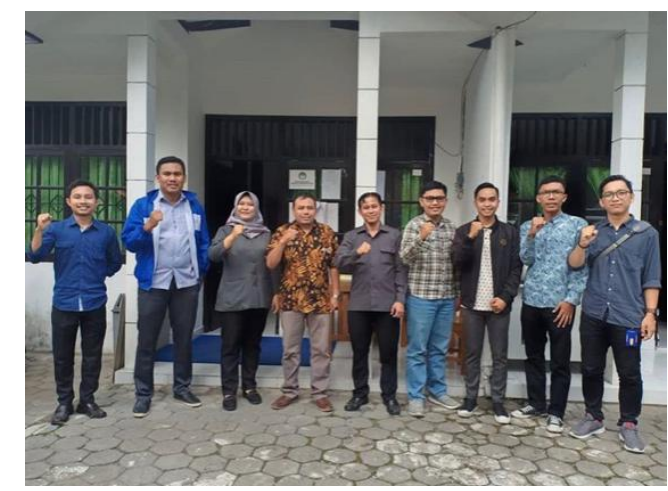

Gambar 1. KISP Mendorong BAWASLU Kabupaten Sleman Untuk Menjadikan Desa Sardonoharjo Sebagai salah satu Pilot Project Desa APU.

Sumber: Media Sosial Instagram KISP

Seiring perjalanan program Desa APU mulai merambah untuk menambahkan berbagai Organisasi Masyarakat (Ormas) dari Nahdatul Ulama (NU) dan Muhammadiyah, Gabungan LSM, Tokoh masyarakat serta Mahasiswa Universitas Muhammadiyah Yogyakarta yang sedang melaksanakan Kuliah Kerja Nyata (KKN) untuk ikut andil dalam program Desa APU di Desa Sardonoharjo. 


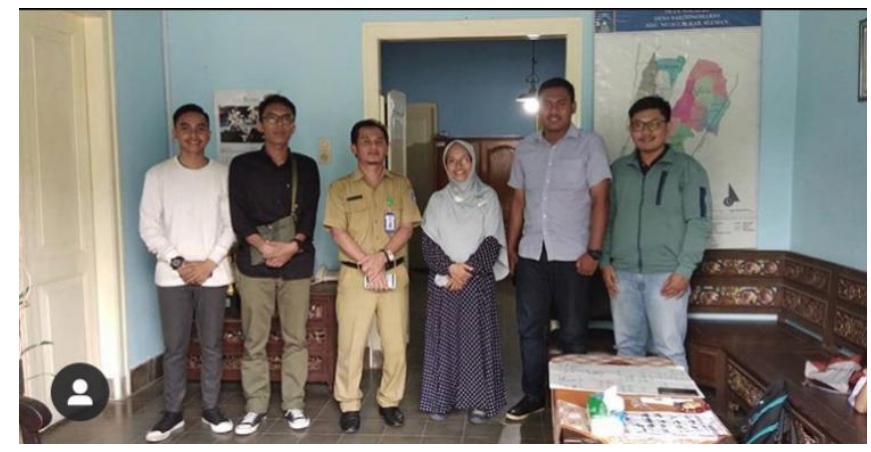

Gambar 2. KISP Bersama Perangkat Desa Sardonoharjo dan Tokoh Masyarakat Sepakat Mengenai Pembentukan Desa APU di Desa Sardonoharjo Sumber: Media Sosial Instagram KISP

KISP hadir dalam progam Desa Sardonoharjo untuk memberikan konsep serta terjun langsung untuk melakukan gerakan perlawanan sosial terhadap praktik politik uang. Hal ini sejalan dengan yang digambarkan oleh Sukmana (2013), gerakan sosial perlawanan berbeda dengan bentuk aksi masa, kerumunan, kerusuhan serta bentuk revolusi untuk megubah suatu keadaan. Hal yang membuat berbeda adalah gerakan sosial perlawanan tidak selalu menggunakan kekerasan fisik atau gerakan mengangkat senjata untuk melawan keadaan yang dianggap salah, namun hal yang dimaksud dalam konteks gerakan perlawanan sosial disini adalah dengan melakukan aksi nyata seperti pengelolaan masyarakat, literasi pendidikan, pembuatan berbagai pelatihan dan lain sebagainya dengan tujuan untuk memperbaiki keadaan sosial masyarakat dari keterpurukan berkelanjutan.

Program Desa APU yang berlokasi di Desa Sardonoharjo memiliki tahapan yang sudah dikonsepkan oleh KISP dengan melibatkan tim yang meliputi perangkat desa, ormas keagamaan, tokoh masyarkat, gabungan LSM dan Bawaslu Kabupaten Sleman. Tahapan berjalannya Desa APU yang berlokasi di Sardonoharjo telah digambarkan dalam gambaran sederhana sebagai berikut: 
POLITICON : Jurnal Ilmu Politik Vol.2 No.2 ; Hal 165-190

Website : http://journal.uinsgd.ac.id/index.php/politicon ISSN : 2685-6670 ( Online )

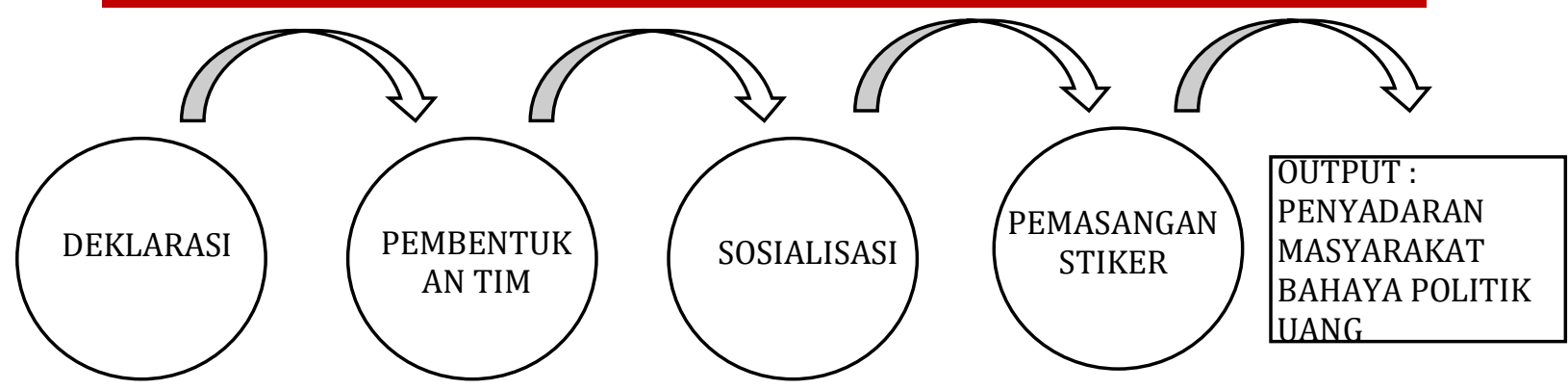

Gambar 3 . Alur Tahapan berjalanya Desa APU Yang berlokasi di Desa Sardonoharjo

Peran KISP dalam gerakan perlawanan sosial Desa APU meliputi mengemas deklarasi, pembentukan tim, kegiatan sosialisasi, pembuatan modul Desa APU dan pembuatan stiker.

\section{Deklarasi Pembentukan Desa APU}

Pada tahap deklarasi, KISP menjadi salah satu konseptor untuk mengemas bagaimana konsep deklarasi Desa APU berjalan. Deklarasi ini menjadi sebuah pembentukan komitmen awal sebelum melaju pada tahap selanjutnya. Selain itu deklarasi ini menjadi sebuah peringatan awal kepada para caleg untuk tidak melakukan praktik politik uang di Desa Sardonoharjo. Banyak pihak yang sengaja diundang dalam acara deklarasi Desa APU, seperti dari pihak ormas keagamaan seperti NU dan Muhammadiyah, Tokoh Masyarakat, gabungan LSM, RT/RW, Tokoh Masyarakat, DPRD, Parpol, Caleg, Bawaslu Kabupaten Sleman, Bawaslu RI dan masyarakat.

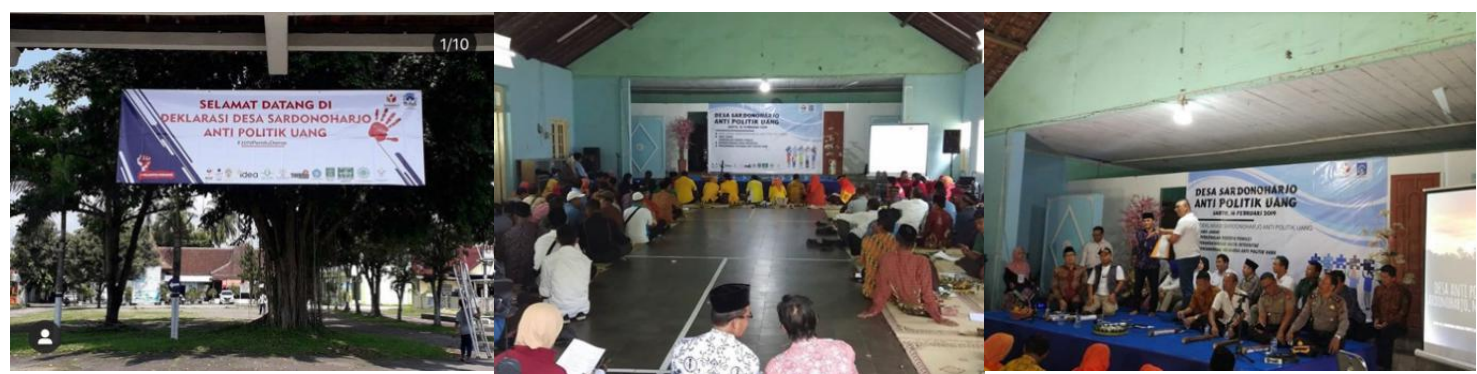

Gambar 4. Deklarasi Desa APU di Desa Sardonoharjo DIY Sumber: Media Sosial Instagram KISP

Berdasarkan pernyataan dari semua informan terkait, semua pihak yang diundang datang dan menyetujui akan sebuah gerakan untuk melawan politik uang. Gerakan sosial yang dilakukan KISP sebagai salah satu konseptor Desa APU berperan untuk menumbuhkan kesadaran kolektif masyarakat Desa Sardonoharjo pada tahapan deklarasi dan terbilang cukup berhasil untuk 
menghidupkan atmosphere perlawanan terhadap politik uang. Hal ini sejalan dengan apa yang dikemukakan oleh Giddens (1976) mengenai gerakan sosial, bahwasanya gerakan sosial merupakan upaya untuk mengejar suatu kepentingan bersama atau untuk mencapai tujuan bersama melalui tindakan kolektif (collective action).

Dalam tahapan deklarasi, para aktor dalam Desa APU termasuk KISP juga melakukan sosialisasi mengenai bahaya dari praktik politik uang. Berdasarkan pernyataan dari semua informan terkait ditambah observasi lapangan saat kejadian secara langsung, metode yang digunakan merupakan metode yang mudah dimengerti oleh masyarakat. Metode yang digunakan adalah bagaimana caranya memberikan pemahaman kepada masyarakat dengan perhitungan uang Rp.100.000,00 (politik uang) dibagi 5 tahun kedepan, sehingga akan didapat nominal yang sangat kecil jika dibagi 1.825 hari (5 tahun). Dengan hal ini diharapkan masyarakat sadar bahwasanya harga satu suara masyarakat hanya dibeli dengan harga yang relatif murah.

Selain itu pada tahapan deklarasi, penandatangan pakta integritas dalam memperkuat komitmen awal untuk melawan praktik politik uang juga terjadi. Pada tahapan ini para caleg juga diminta untuk menyampaikan visi \& misi yang mereka miliki, dengan harapan masyarakat mengenal caleg-caleg tersebut.

\section{Pembentukan Tim Relawan Desa APU}

Pada tahap pembentukan tim, perangkat desa membuat Surat Keterangan (SK) mengenai perlindungan secara hukum terhadap tim yang bertugas sebagai bagian dari pembentukan program Desa APU. Ini artinya bahwa ada tindakan serius mengenai pemberlakuan tim relawan Desa APU dalam menjalankan tugas. Elemen yang tergabung dalam proses Pembentukan Tim adalah KISP dan gabungan LSM lainnya, Ormas seperti Muhammadiyah dan NU dan Tokoh Masyarakat. Terbentuknya tim relawan Desa APU didasari dari kesamaan nasib KISP dan berbagai elemen di dalam tim relawan Desa APU yang menginginkan sebuah perubahan untuk melawan praktik politik 
POLITICON : Jurnal Ilmu Politik Vol.2 No.2 ; Hal 165-190

Website : http://journal.uinsgd.ac.id/index.php/politicon

ISSN : 2685-6670 ( Online )

uang di Desa Sardonoharjo, sehingga menurut Soekanto (2012) hal ini dapat merangsang terbentuknya sebuah kelompok sosial untuk mencapai sebuah tujuan tertentu seperti Tim Relawan Desa APU.

\section{Sosialisasi dan Pendidikan Politik di Desa APU}

Pada tahapan sosialisasi dan pendidikan politik yang dilakukan oleh Tim Relawan Desa APU, KISP memiliki peran vital dalam tahapan ini. Tim relawan KISP telah membuat jadwal rutin mengenai siapa saja yang turun ke setiap pertemuan masyarakat untuk melakukan sosialisasi bahaya praktik politik uang. Namun dalam prakteknya antusiasme tim relawan Desa APU terbilang cukup kurang sehingga banyak yang hilang saat gilirannya tiba.

Dalam tahapan ini KISP terjun secara langsung untuk memberikan sosialisasi dan pendidikan politik mengenai dampak buruk politik uang bersama satu tokoh masyarakat wanita penggagas program Desa APU di Desa Sardonoharjo. KISP hadir untuk menjelaskan sosialisasi bahaya praktik politik uang di setiap agenda pertemuan warga seperti rapat rutin RT/RW, ritual pengajian dan berbagai jenis pertemuan lainya di tingkat masyarakat. Karena berdasarkan dari studi Utari (2016) menjelaskan bahwasanya proses pencegahan praktik politik uang harus dilaksanakan dengan pendidikan politik secara berkala di dataran masyarakat.

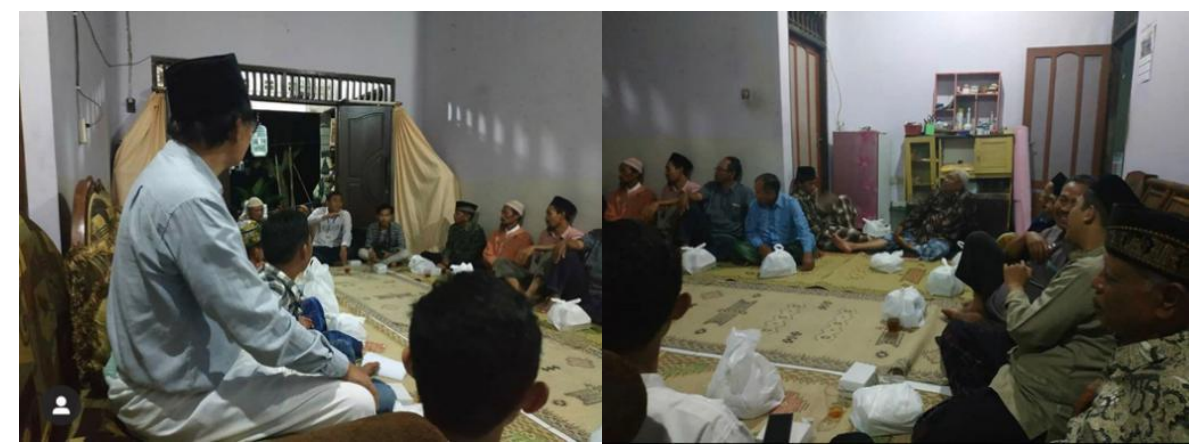

Gambar 5. Sosialisasi Bahaya Politik Uang di Setiap Pertemuan Warga Sumber: Media Sosial Instagram KISP

Pihak perangkat desa khususnya sekretaris desa dan Bawaslu Kabupaten Sleman selaku informan terkait di dalam program ini mengaku bahwasanya mereka merasa terbantu dengan kehadiran KISP sebagai perpanjangan tangan mereka untuk membantu melawan praktik politik uang 
di tingkat grassroot, alasanya adalah Desa Sardonoharjo merupakan desa yang cukup luas serta tidak mungkin perangkat desa dan Bawaslu Kabupaten Sleman bisa mencakup semua untuk turun di tingkat RT/RW dalam proses sosialisasi bahaya praktik politik uang. Di sisi lain, ini adalah kali pertama ada yang turun untuk ikut andil dalam upaya pengentasan praktik politik uang di tingkat grassroot, hal ini mengindikasikan bahwasanya Desa Sardonoharjo belum pernah tersentuh literasi politik mengenai upaya pengentasan praktik politik uang dari pihak manapun.

Namun, upaya KISP dalam melakukan sosialisasi mengenai bahaya praktik politik uang tidak selamanya disambut baik oleh masyarakat Desa Sardonoharjo. Dalam prosesnya, antusiasme masyarakat Desa Sardonoharjo masih terbilang relatif kurang. Hal ini dibuktikan dari tindakan masyarakat yang memilih untuk meninggalkan lokasi saat program sosialisasi berlangsung, masyarakat memilih untuk keluar dari lokasi secara bertahap meski program sosialisasinya belum selesai. Bahkan tindakan pengusiran secara halus tim relawan KISP saat keberlangsungan program sosialisasi sempat terjadi, dengan alasan mereka tidak membutuhkan hal tersebut.

Kesadaran masyarakat mengenai bahaya praktik politik uang di Desa Sardonoharjo masih terbilang relatif rendah, hal ini didukung oleh pernyataan perangkat desa yang cenderung kurang tegas dalam upaya pengentasan praktik politik uang di Desa Sardonoharjo.

"kami dari perangkat desa menerima kehadiran KISP di dalam program Desa APU yang dilaksanakan di Desa Sardonoharjo untuk mencerdaskan masyarakat kami perihal bahaya praktik politik uang, tetapi ini adalah sistem demokrasi 5 tahunan yang artinya saya tidak bisa melarang masyarakat untuk menerima budaya politik uang. Karena tidak ada jaminan bahwa jika mereka tidak menerima budaya politik uang otomatis aspirasi mereka akan terpenuhi oleh caleg jika terpilih nantinya, jadi jika saya melihat ada praktik politik uang pun saya akan kembalikan lagi ke masyarakat dan terserah mereka akan menerimanya atau tidak karena kami tidak punya wewenang akan hal itu." (13/03/2020)

Kalimat di atas merupakan pernyataan secara langsung saat proses wawancara dari perangkat desa khususnya Sekretaris Desa Sardonoharjo 
yang mengindikasikan sebuah tindakan kurang tegas dan bertolak belakang dalam tahapan sosialisasi bahaya praktik politik uang oleh KISP. Hal tersebut juga memberikan sebuah gambaran jika politik uang sudah menjadi hal yang biasa dan bahkan menjadi sebuah budaya rutin 5 tahunan di Desa Sardonoharjo. Sikap pembiaran oleh perangkat desa tersebut akan berimplikasi khusus terhadap berkembangnya budaya buruk mengenai praktik politik uang di Desa Sardonoharjo, sikap ini bisa membuka pintu lebar untuk para caleg dalam melakukan praktik politik uang karena ada hubungan kooperatif untuk merasa saling diuntungkan oleh praktik politik uang antara caleg dan masyarakat.

Hal yang membuatnya menjadi bertambah sulit adalah anggota tim relawan KISP bukanlah masyarakat asli Desa Sardonoharjo, sehingga dibutuhkan seseorang yang memiliki legal standing kuat seperti perangkat desa untuk ikut terjun dalam tahap sosialisasi politik uang di Desa Sardonoharjo. Namun, hal yang sangat disayangkan adalah perangkat desa tidak mengambil peran yang signifikan dan tidak ikut terjun secara langsung untuk menyampaikan sosialisasi terkait bahaya praktik politik uang bersama KISP, sehingga hal ini menjadi sebuah kewajaran jika KISP menerima penolakan secara halus oleh masyarakat setempat saat menjalankan tahapan sosialisasi. Berdasarkan pernyataan dari sekretaris desa selaku informan terkait, alasan dari tidak bergabungnya pihak perangkat desa dalam proses sosialisasi ini karena manajemen waktu yang selalu mengalami benturan antara agenda desa dan proses sosialisasi.

Selain itu, peran dari pihak Bawaslu Kabupaten Sleman hanya hadir saat tahapan deklarasi berlangsung dan kurang dalam andil untuk hadir dalam proses sosialisasi bahaya praktik politik uang di tingkat RT/RW pada berbagai agenda pertemuan warga Desa Sardonoharjo, padahal pada UU No. 7 Tahun 2017 sudah tertulis bahwasanya salah satu tugas Bawaslu adalah untuk melakukan pencegahan praktik politik uang dengan salah satu caranya adalah sosialisasi bahaya praktik politik uang (Sacipto, 2019). Dengan adanya hal ini 
maka kolaborasi antara KISP dengan berbagai aktor penting di program Desa APU sangat sulit menemukan titik temu keselarasan untuk mencapai output yang ingin dicapai yaitu perlawanan terhadap praktik politik uang.

Padahal jika semua elemen dapat bersatu pada tahap sosialisasi untuk memperkuat masyarakat sipil, maka keniscayaan untuk membentuk masyarakat yang sadar akan bahaya politik uang bisa tercapai dan mampu memperbaiki kualitas demokrasi prosedural di Desa Sardonoharjo. Karena masyarakat sipil memiliki pengaruh yang vital dalam proses konsolidasi demokrasi di Indonesia (Hadi, 2010).

\section{Pembuatan Modul Desa APU}

Pada tahapan ini KISP dengan dibantu oleh Jurusan Ilmu Pemerintahan Universitas Muhammadiyah Yogyakarta berperan dalam penyusunan Modul Desa APU. Tujuan dari penyusunan modul Desa APU adalah sebagai sebuah panduan khusus untuk menjalankan program Desa APU, karena modul tersebut berisi pengetahuan umum mengenai pemilu, politik uang, demokrasi, partai politik, penyelenggara pemilu dan metode penyampaian edukasi politik yang sudah disertakan bersama materi yang mudah dimengerti oleh berbagai kalangan masyarakat.

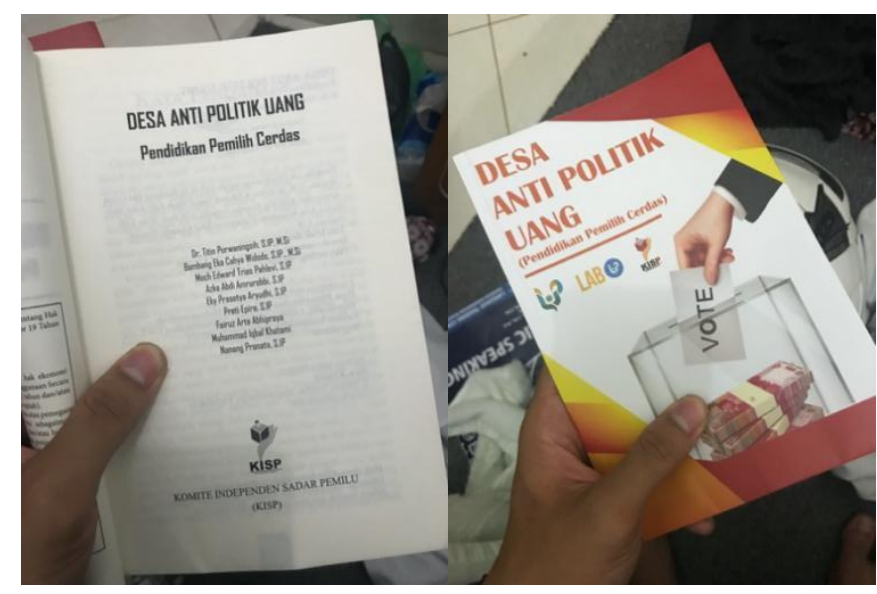

Gambar 6. Modul Desa APU yang dibuat oleh KISP dan Jurusan Ilmu Pemerintahan Universitas Muhammadiyah Yogyakarta

Modul Desa APU telah dibagikan ke semua aktor di dalam program Desa APU seperti perangkat desa, Bawaslu Kabupaten Sleman, tokoh masyarakat, ormas keagamaan, gabungan LSM dan masyarakat umum serta 
POLITICON : Jurnal Ilmu Politik Vol.2 No.2 ; Hal 165-190

Website : http://journal.uinsgd.ac.id/index.php/politicon

ISSN : 2685-6670 ( Online )

pemuda karang taruna di Desa Sardonoharjo. Suatu hal yang menjadi harapan KISP adalah agar kedepanya akan hadir sebuah gerakan serupa untuk upaya melawan praktik politik uang di Desa Sardonoharjo, di mana akan menjadi sebuah agenda rutin setiap lima tahun sekali, maka dari itu KISP membagikan Modul Desa APU ke berbagai aktor khususnya kepada kelompok pemuda Karang Taruna yang harapannya akan menjadi penerus program Desa APU di Desa Sardonoharjo. Namun, hal yang disayangkan adalah tidak ada pemuda Karang Taruna yang bersedia untuk meneruskan program tersebut, sehingga sejauh ini agenda pendidikan politik hanya dijalankan di kalangan ibu-ibu di Desa Sardonoharjo dan dipimpin oleh salah satu tokoh masyarakat wanita yang tinggal di Desa Sardonoharjo.

\section{Pembuatan Stiker}

Dalam tahapan ini, KISP berperan untuk membuat stiker bertulisan "kami keluarga anti politik uang". Sasaran dari pembuatan stiker ini adalah dibagikan ke masyarakat sekitar saat sosialisasi berlangsung dan saat deklarasi dilaksanakan yang diharapkan untuk memasangnya di depan rumah warga masing-masing. Harapan besar dari pemasangan stiker ini adalah untuk mencegah caleg datang ke rumah dan menawarkan politik uang ke masyarakat.

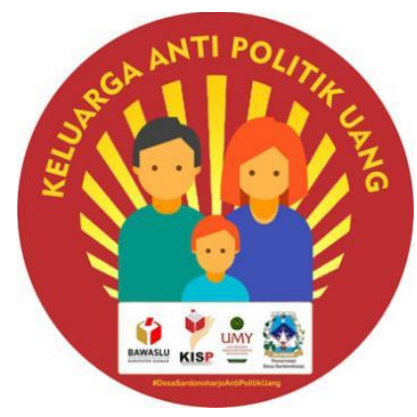

Gambar 7. Design Stiker Desa APU untuk Ditempel di Setiap Rumah Warga

\section{Pembaharuan Pasca Kehadiran KISP}

Dengan kehadiran KISP sebagai LSM kepemiluan di Desa Sardonoharjo dalam agenda pengentasan praktik politik uang, pihak perangkat desa dan 
POLITICON : Jurnal Ilmu Politik Vol.2 No.2 ; Hal 165-190

Website : http://journal.uinsgd.ac.id/index.php/politicon ISSN : 2685-6670 ( Online )

Bawaslu Kabupaten Sleman merasa terbantu dengan adanya kehadiran KISP. Bahkan berdasarkan pernyataan dari Bawaslu Kabupaten Sleman dan Perangkat Desa Sardonoharjo, KISP adalah LSM kepemiluan pertama yang hadir di tingkat grassroot untuk melakukan gerakan moral pembaharuan untuk melawan praktik politik uang.

Karena peran KISP dalam program Desa APU adalah untuk membangun sumberdaya manusia yang sadar akan bahaya politik uang. Tipologi LSM yang dimiliki KISP adalah tipe reformis yang dasar pemikiran didasari pada ideologi modernisasi dan developmentalisme> Artinya bahwa KISP menjunjung paradigma utama pada gerakan ini adalah partisipasi masyarakat untuk melawan praktik politik uang, memotivasi dan membentuk konsepsi masyarakat agar masyarakat bisa secara mandiri melawan praktik politik uang (Fakih, 2010).

Berdasarkan data yang diperoleh oleh Bawaslu Kabupaten Sleman tentang temuan dan laporan mengenai praktik politik uang di Desa Sardonoharjo sebelum terbentuknya Desa APU, pihak Bawaslu Kabupaten Sleman menerima satu laporan yang bersumber dari salah satu warga Desa Sardonoharjo yang menjadi salah satu tim relawan Desa APU mengenai terjadinya praktik politik uang di Desa Sardonoharjo. Dan, kasus itu sudah ditangani oleh pihak Bawaslu Kabupaten Sleman. Namun, setelah berjalannya Desa APU, pihak Bawaslu Kabupaten Sleman tidak menerima satupun laporan atau temuan mengenai praktik politik uang di Desa Sardonoharjo sampai pemilu serentak 2019 selesai.

Hal ini bukan satu-satunya variabel penelitian yang mengindikasikan keberhasilan KISP dalam sosialisasi bahaya praktik politik uang di Desa APU. Seperti yang ditegaskan oleh Sekretaris Desa Sardonoharjo mengenai bagaimana sikap pembiaran perangkat desa mengenai praktik politik uang di Desa Sardonoharjo justru mengindikasikan sebaliknya. Ketika perangkat desa bertindak kurang tegas terhadap praktik politikuang dan bahkan membiarkan hal itu terjadi maka akan ada sebuah bentuk kooperatif antara masyarakat 
dengan pelaku politik uang untuk sama-sama diuntungkan dengan pola hubungan patron-klien. Hal ini akan berdampak pada sulitnya mendapat laporan dan temuan Bawaslu Kabupaten Sleman, karena masyarakat dengan pelaku politik uang akan berusaha 'bermain aman' agar masyarakat tidak melapor dan berusaha agar tidak tertangkap pihak pengawas pemilu saat membagikan barang patron tersebut.

Hal ini juga ditegaskan oleh Koordinator Umum KISP selaku informan terkait, bahwasanya mereka menganggap program Desa APU yang berada di Desa Sardonoharjo kurang efektif karena antusiasme para aktor Desa APU dan Perangkat Desa Sardonoharjo yang kurang mengambil peran signifikan untuk proses sosialisasi membuat keadaan semakin sulit. Namun, di sisi lain berdasarkan pernyataan dari pihak perangkat desa yang menyatakan bahwa dengan kehadiran KISP di Desa APU, masyarakat Desa Sardonoharjo sudah mulai 'mencerdaskan' dan 'mengerti' mengenai dampak buruk dari praktik politik uang, minimal ada sebuah kebangkitan sisi religius yang menjadi dasar bahwa praktik politik uang adalah perbuatan tercela dalam agama.

Namun, terlepas dari hal tersebut, ketiga informan terkait menjelaskan bahwasanya sangat sulit mengubah kebiasaan masyarakat Desa Sardonoharjo untuk menerima sebuah pemberian dari seseorang. Karena hal tersebut sudah menjadi sebuah budaya yang mengakar di Desa Sardonoharjo, di garis yang sama pihak sekretaris desa menegaskan bahwa masyarakatnya sangat pantang untuk menolak "rejeki" yang sudah datang kepada mereka, namun perihal mereka akan memilih caleg yang menggunakan sarana politik uang atau tidak semua diserahkan kepada masyarakat Desa Sardonoharjo.

Pembaharuan juga terjadi dari keluarnya Peraturan Kepala Desa Sardonoharjo (Perkades) Nomor 1 Tahun 2019 mengenai program Desa APU. Isi dari Perkades tersebut membahas mengenai penguatan masyarakat Desa Sardonoharjo untuk bersama-sama melawan praktik politik uang. Desa Sardonoharjo adalah desa pertama di Indonesia yang memiliki Perkades mengenai perlawanan terhadap praktik politik uang (Panji, 2019). Namun 
pengeluaran Perkades tersebut akan menjadi sebuah ajang formalitas belaka sebagai desa yang melawan praktik politik uang, karena dalam praktiknya justru berlawanan dengan isi dari Perkades tersebut sehingga bisa dikatakan hal ini kurang efektif.

\section{SIMPULAN}

Penelitian ini telah menjawab peran KISP sebagai LSM Kepemiluan dalam pembentukan Desa APU di Desa Sardonoharjo, Daerah Istimewa Yogyakarta sebagai media penguatan demokrasi di dataran grassroot. Peran penguatan masyarakat sipil yang dilakukan KISP, yaitu, dengan aktif bergerak memberdayakan masyarakat diberbagai elemen untuk lebih mandiri melawan praktik politik uang, memalui tahapan yang terorganisir dalam pembentukan desa APU yang meliputi deklarasi anti politik uang desa APU, pembentukan tim, sosialisasi pendidikan politik uang, hingga pada pembuatan modul Desa APU dan pembuatan stiker keluarga anti politik uang. Sehingga hal ini menjadi salah satu faktor yang merangsang terbentuknya Perkades Nomor 1 Tahun 2019 mengenai program Desa APU di desa Sardonoharjo sebagai satu-satunya desa yang telah menerapkan perlawanan praktik politik uang.

Namun, di balik peran KISP dalam pembentukan Desa APU belum bisa disebut telah berhasil memberantas praktik politik uang secara menyeluruh di Desa APU, karena masih ada penolakan dari masyarakat atas gerakan tersebut. Hal ini disebabkan oleh sikap perangkat desa yang kurang tegas untuk melawan praktik politik uang dan kurangnya partisipasi Bawaslu Kabupaten Sleman dalam tahapan sosialisasi, padahal upaya dalam tahapan sosialisasi membutuhkan tokoh yang memiliki Legal Standing dan wewenang yang lebih kuat dalam menjalankan tahapan sosialisasi tersebut, mengingat tim relawan KISP bukanlah kelompok orang asli yang menetap di Desa Sardonoharjo. Meskipun tidak ada temuan dan laporan mengenai praktik politik uang di Desa Sardonoharjo setelah adanya program Desa APU, hal ini tidak mengindikasikan keberhasilan program tersebut untuk mengentaskan praktik politik uang, karena bisa saja ada bentuk 'kerja sama' antara pelaku politik 
POLITICON : Jurnal Ilmu Politik Vol.2 No.2 ; Hal 165-190

Website : http://journal.uinsgd.ac.id/index.php/politicon

ISSN : 2685-6670 ( Online )

uang dan masyarakat agar tidak 'tertangkap basah' oleh Bawaslu Kabupaten Sleman.

\section{DAFTAR PUSTAKA}

Anggraeni, L., \& Ramdhani, H. (2018). Pencegahan Money Politic Dalam Pemilihan Umum Melalui Penguatan Kebijakan Non Penal. Jurnal Komunikasi Hukum (Jkh). Https://Doi.Org/10.23887/Jkh.V4i1.13660

Aspinall, E., \& Berenschot, W. (2019). Democracy For Sale Elections, Clientalism, And The State In Indonesia. In Cornell University Press.

Aspinall, E., \& Sukmajati, M. (2018). Patronage And Clientelism In Indonesian Electoral Politics. In Electoral Dynamics In Indonesia. Https://Doi.Org/10.2307/J.Ctv1xxzz2.7

Chandra, M. J. A., \& Ghafur, J. (2020). Peranan Hukum Dalam Mencegah Praktik Politik Uang (Money Politics) Dalam Pemilu Di Indonesia: Upaya Mewujudkan Pemilu Yang Berintegritas. Wajah Hukum, 4(1), 52-66.

Culla, A. S. (1999). Masyarakat Madani Pemikiran Teori Dan Relevansinya Dengan Cita-Cita Reformasi. Jakarta: Raja Grafindo.

Fakih, M. (2010). Masyarakat Sipil Untuk Transformasi Sosial: Pergolakan Ideologi Lsm Indonesia (5th Ed.). Yogyakarta: Insist Press.

Giddens, A. (1976). Classical Social Theory And The Origins Of Modern Sociology. American Journal of Sociology. Https://Doi.Org/10.1086/226140

Hadi, O. H. (2010). Peran Masyarakat Sipil Dalam Proses Demokratisasi. Makara Human Behavior Studies In Asia. Https://Doi.Org/10.7454/Mssh.V14i2.674

Hermawan, I. (2019). Metodologi Penelitian Pendidikan (Kualitatif, Kuantitatif Dan Mixed Method). Hidayatul Quran.

Huntington, S. P. (1993). The Third Wave: Democratization In The Late Twentieth Century (Vol. 4). University Of Oklahoma Press.

Lukmajati, D. (2016). Praktek Politik Uang Dalam Pemilu Legislatif 2014 (Studi Kasus Di Kabupaten Blora). Jurnal Ilmu Politik Undip, Volume 7.

Manan, H. A., \& Sh, S. (2018). Dinamika Politik Hukum Di Indonesia. Kencana.

Marsudi, K. E. R., \& Sunarso, S. (2019). Revitalisasi Pendidikan Politik Melalui Pembentukan Kampung Anti Money Politic. Jppuma Jurnal Ilmu 
POLITICON : Jurnal Ilmu Politik Vol.2 No.2 ; Hal 165-190

Website : http://journal.uinsgd.ac.id/index.php/politicon

\section{ISSN : 2685-6670 ( Online )}

Pemerintahan Dan Sosial Politik Universitas Medan Area. Https://Doi.Org/10.31289/Jppuma.V7i2.2303

Muhtadi, B. (2013). Politik Uang Dan Dinamika Elektoral Di Indonesia: Sebuah Kajian Awal Interaksi Antara "Party-Id" Dan Patron-Klien. Jurnal Penelitian Politik, 10(1), 17.

Mukhsid, W. (2015). Upaya Panitia Pengawas Pemilu Kabupaten Banyumas Dalam Pencegahan Tindak Pidana Money Politic Pada Pemilihan Umum Legislatif Tahun 2014. Jurnal Idea Hukum. Https://Doi.Org/10.20884/Jih.V1i2.22

Myers, D. G. (2012). Introducing Social Psychology. Social Psychology.

Nawawi, H. (2015). Metode Penelitian Bidang Sosial. Yogyakarta: Ugm Press.

Panji, A. (2019). Sardonoharjo, Desa Pertama Yang Punya Perkades Antipolitik Uang. Kumparan.Com, P. Politik.

Pranata, N. Y. (2019). Strategi Mencegah Money Politic Melalui Desa Anti Politik Uang. Repository.Umy.Ac.Id.

Putra, M. T. N., Sunarto, \& Raharjo, E. (2018). Upaya Penanggulangan Politik Uang (Money Politic) Pada Tahap Persiapan Dan Pelaksanaan Pilkada Serentak Di Provinsi Lampung. Journal Of Chemical Information And Modeling. Https://Doi.Org/10.1017/Cbo9781107415324.004

Kurniawan, D. H. (2019). Strategi Sosial Pencegahan Politik Uang Di Indonesia. Jurnal Integritas Kpk 2019.

Sacipto, R. (2019). Kajian Praktik Money Politics Dalam Penyelenggaraan Pemilihan Umum Sebagai Cikal Bakal Tindak Pidana Korupsi. Adil Indonesia Journal, 1(2).

Setyawan, D., \& Adiwidjaja, I. (2013). Strategi Meningkatkan Kesadaran Politik Dan Menolak Money Politic Pemilih Pemula Pada Pilkada Kota Malang. Jurnal Reformasi.

Soekanto, S. (2012). Sosiologi Suatu Pengantar. Jakarta: Raja Garafindo Persada.

Sukmana, 0. (2013). Konvergensi Antara Resource Mobilizationtheory Dan Identityoriented Theorydalam Studi Gerakan Sosial Baru. Jurnal Sosiologi Reflektif, 8(1), 39-62.

Sumarmo, U. (2010). Teori, Paradigma, Dan Pendekatan Pembelajaran Mipa Dalam Konteks Indonesia. Jakarta: Universitas Pendidikan Indonesia. 
POLITICON : Jurnal Ilmu Politik Vol.2 No.2 ; Hal 165-190

Website : http://journal.uinsgd.ac.id/index.php/politicon ISSN : 2685-6670 ( Online )

Sumarto, M. (2018). Perlindungan Sosial Dan Klientelisme: Makna Politik Bantuan Tunai Dalam Pemilihan Umum. Ugm Press.

Utari, S. (2016). Pencegahan Politik Uang Dan Penyelenggaraan Pilkada Yang Berkualitas: Sebuah Revitalisasi Idelogi. Seminar Hukum Nasional.

Wilson, J. (2012). Volunteerism Research. Nonprofit And Voluntary Sector Quarterly. Https://Doi.Org/10.1177/0899764011434558

Zubaedi, M. A. (2016). Pengembangan Masyarakat: Wacana Dan Praktik. Kencana. 